\title{
CONSIDERATIONS \\ ON FRACTIONAL RESERVE BANKING AND FREE-BANKING
}

\author{
RAFAEL HOTZ
}

In this article, our goal is to examine a controversy very dear to Austrian economists: that of the legitimacy of the fractional reserve banking system, defined as a system in which the bankers keep in their vaults a quantity of money (narrowly defined) lower than the quantity of cash deposits granted to their clients.

In the Austrian vision, the monetary supply, broadly defined (Mises, 1971), consists of money properly said, plus monetary substitutes (bank notes, cash deposits), plus credit-money, this one corresponding to any future right to a monetary sum (time deposits, promissory notes, pre-fixed derivatives). In a narrow sense, money supply consists in money properly said (fiat-money or commodity money).

We must, however, clarify some aspects of the money supply.

Monetary substitutes have their origin in the monetary certificates. Monetary certificates, in their turn, are tools utilized to confer information about the medium of exchange. For instance, precious metal coins mintage confers information about the metal's purity and about the weight of the coin; bank notes and current account balances confer information about the amount, overseer and proprietor of the deposited money. So, money certificates can change the agents' valuations concerning the particular good in question, even being able of independent valuation. Monetary certificates can be physically connected to the medium of exchange or separated from it. In the case of physically connected monetary certificates, we have what we normally call monetary substitutes. Monetary substitutes can, due to their nature, work as property titles to the very medium of exchange. Contemporaneously, monetary substitutes usually can be identified with cash deposits 
(current account balances) and paper checks, provided that the use of bank notes is increasingly rare.

Having made those clarifications concerning monetary substitutes, we will, following Mises (1971, p. 135), call fiduciary media the quantity of monetary substitutes that exceeds the quantity of money properly said.

However, before proceeding with our Investigation about the consequences of the legalization of the production of fake monetary substitutes (fiduciary media), we must explain what would be a fake monetary substitute and the nature of this counterfeiting. We must, therefore, start our argumentation establishing some differences about the nature of loan and deposit contracts $[\mathrm{x}]$.

Loan contracts can be classified in two ways. The first one is the commodatum contracts, in which one agent (creditor) temporarily concedes the availability of a certain good to another agent (debtor), who must return the good at the end of the pre-fixed period in appropriate conditions. The second one is the mutual (mutuum) contracts, a little bit more complex. In those, the creditor grants the debtor property over a sum of fungible goods [x] (tantundem, in Latin), in exchange for the future property over another sum of fungible goods.

Deposit contracts, in their turn, involve the transference of the custody over a certain good by one agent (depositor) to another (depositary). That is, at any moment whatsoever, when a depositor firms a deposit contract, he is granting the depositary availability (even less property) over the deposited tantundem. A particular kind of deposit is the irregular deposit contract. This contract relates to the deposit of fungible goods. Because of the nature of the goods deposited, they probably will get mixed up unless significant costs are incurred in their isolation. Therefore, the depositary's duty is to grant immediate availability to the depositor to a tantundem correspondent to that initially deposited.

We are now in a position to explain the main differences about deposit and loan contracts.

In the deposit contract there aren't any property titles transferred. In a loan contract, the situation is completely different. The creditor 
realizes an intertemporal exchange with the debtor. The creditor agrees with parting with the tantudem's availability during the loan period. The debtor, in exchange, compromises to deliver a future good (in a quantity presumably greater) at the end of the accorded period. Yet, in a deposit contract, the depositor simply wishes that the depositary act as a protector of the tantundem. There aren't exchanges between present goods and future goods. The depositary can offer some services, such as withdrawing services at different places and under different forms, and be remunerated for those services. But in any form the depositor has parted with the control of the destiny of the monetary units trusted to the depositary's guard. Briefly, when an agent makes a deposit contract, what he has in mind is that his cash holdings are at a certain figure. In an intertemporal exchange, the agent is aware of alterations in his cash holdings.

Explicited the differences between a deposit and a loan contract, we must relate this concepts to the production of monetary substitutes and to the problem of their counterfeiting.

In a loan contract, the debtor receives from the creditor money properly said, whereas the creditor receives a payment promise, that, securitized, is capable of being negotiated at some secondary market as credit-money. Still, the depositary, when realizing a deposit, normally receives from the depositor a monetary certificate physically separated from the deposited amount, that is, a monetary substitute. What are the logical consequences of those fats? Credit-money can be issued without any legal limits whatsoever, since its emission presupposes the intertemporal exchange of property titles. The risks imminent to this operation, in a unhampered economy, are completely internalized by the agents. However, there is a legal limitation over the issuance of monetary substitutes: these must always match the deposited amount. Why?

The correspondence between issued monetary substitutes and the tantundem follows from the very nature of a deposit contract - the depositary must grant the depositor full and continuous availability over the tantundem. To support our reasoning, let's suppose that the depositary have issued a quantity of monetary substitutes greater than the deposited tantundem - that he has 
issued fiduciary media. Clearly the depositary is incurring in a breach of contract with his depositors. If all owners of the monetary substitutes at any moment physically demand what's rightfully theirs, that is, the immediate availability of the deposited amount (as demonstrated by the redemption of the monetary substitutes), the depositor will not be able to accomplish all his contractual duties. A good metaphor for this situation would be that of comparing the depositary with a parking lot owner. A depositary that issues fiduciary media would act as a parking lot owner that takes the clients' cars for a ride without their consent.

It could be argued that only at the limit situation described, that is, only when physically the amount required by the monetary substitutes holders exceeds the depositary's reserves, the latter is incurring in fraud. Nonetheless, the deposit contract presupposes full and continual availability over the tantundem to the depositors. It is not sufficient to offer availability to the depositors only at the moment that these physically demand the redemption of their monetary substitute. The availability must be continually kept for all the depositors, because all depositors have a right to withdraw their tantundem at any moment they wish (concomitantly or not). The conclusion is that the depositary is already incurring in fraud at the moment he issues fiduciary media (fake monetary substitutes).

Then, as explained by Huerta de Soto (2006, p. 666), we can see that the problem of the fiduciary media is a classic tragedy of the commons problem, i.e., a situation in which there aren't correctly delimited property rights. All the holders of monetary substitutes subjectively believe that they have property rights over some monetary sum, and consider it at the moment they elaborate their plans of action. We can conclude that the legalization of fiduciary media represents a direct intervention over entrepreneurial activity, then being a factor of discoordination over the economic system.

Though, a new question deserves an answer. What would be the legal bank reserve level in an unhampered economy, that is, one without institutionalized aggression and coercion?

Suppose you have $\$ 100$ and decided to enter the financial intermediation industry. You decide to buy a vault, keep these 
\$100 inside, and issue notes with the following writings: «It can be exchanged here at my vault at any moment for $\$ 1$ ». If you issue 100 similar notes and sell them with any surplus (because of the safeguarding services), there are no problems with that. But, if you issue and sell more than a hundred of them, you are cheating your customers. Why?

Suppose you have issued 150 similar notes, sold 100 notes for one person and 50 notes for another. You are saying one thing: I grant you, respectively, full and continual availability of $\$ 100$ and \$50; and you are not performing your part of the deal - if both appear together at any moment to redeem their notes, you will not be capable of keeping your promises.

Does all this mean that you cannot anyhow issue more than 100 notes? No.

You could issue notes with the following writings: «It can be exchanged here at my vault for $\$ 1$, at any money, if possible». Pay attention to the difference of the notes with and without the «if possible» clause. You could issue and sell how much of them you desired, because there is an explicit consent by the buyers that it is a risky contract, in which the full availability is not granted. It amounts to credit-money issuance, not fiduciary media.

Now, two additional difficulties. The first one is the fact that the banks have third parties deposits among their own capital. The bankers could never reduce their reserves to a figure lower than the amount possessed by their clients, because it would consist in misappropriation. So, in our example, the banks would necessarily have to deny the redemption of those risky notes as soon as the reserves reach the quantity correspondent to the deposits of the customers of the first kind of note. This means that the banks can only issue fiduciary media against the reserves of third parties willing to suffer the abuses inherent to the fractional reserve system (never against those of non willing third parties) and only explicitly (besides being able to issue credit-money against their own reserves).

Adepts of the full reserves system usually argue that the issuance of fiduciary media, even under the consented system described above, causes externalities, since it reduces the purchasing power of money and engenders business cycles, due to the artificial 
lengthening of the capital structure. All of this, despite being theoretically true, at practice would not represent a real serious problem, neither would constitute legal basis to prohibit it under the conditions described above. Why?

The agents, as I wrote, would demand information about the origin of the assets utilized (bank note specifications or information about the bank account they become creditors and/or debtors). They would have to consent with the loss of purchasing power of their money. Medium of exchange whose supply does not rise overdue to the effects caused by the fiduciary media, ceteris paribus immunes to a tendency of depreciation in its purchasing power, would find a lot more customers in an unhampered economy, compared to medium of exchange whose supply is more elastic. And, as the primordial function of money is being a medium of exchange, fiduciary media would tend to be eliminated from the market because of the competition with more stable medium of exchange, with greater demand and higher purchasing power.

The second difficulty, related to the first one, resides on the fact that the banks do not have the habit anymore of using banknotes. The cash deposits consist in numbers in a computer system. To avoid fraud, the clients would probably demand public availability of banks' solvency data. Probably another service would arise (in practice, another monetary certificate), that of bank account monitoring, to assure that the banks do not incur in fraudulent operations. The banks would have to arrange special «risky» accounts to practice fiduciary media issuance and be monitored. In fact, the theoretical classification of the diverse «financial products» present at recent economic history, as much as proves of their legitimacy (respecting property rights and freedom to contract) is something to be realized with carefully. As notes Huerta de Soto (2006, cap. 3), the fractional reserve banking system has been working «hidden» and protected by fiat interventionist legislation in markets such as insurance and derivatives markets.

Now, under the light of our analysis, we shall weave a brief comment about the doctrine of free-banking, to which some Austrians consider themselves adept. 
Free-banking theorists does not think that fractional reserves necessarily create problems, such as business cycles. Furthermore, they consider it as being necessary to maintain the "monetary equilibrium» of the economic system. In brief, they reason, utilizing the tautological equation of exchange, that variations in the demand for money should be countered with variations in the money supply (via fractional reserve banking system, without a Central Bank), whilst variations in the "price level» should be let to operate. They pretend to stabilize «MV», leaving «PT» free of any control. Horwitz (2000, cap. 4), taking as a given the necessity of adjustment, argues that an adjustment via money supply is more efficient than an adjustment via prices due to the fact that prices tend to be sticky, provoking relative price distortions at the adjustment process. Nevertheless, as shows the very Austrian theory, additional expenditure caused by increases in the money supply also provoke relative price distortions - in this case it would be just a matter of preference of the free-bankers for a increase in the money supply over the price adjustment.

We know that the interest rate is determined by the agents' time preference, manifested in the proportion of expenditures on present and future goods. So, rises at the hoarding level can be representing changes in agents' time preferences. Only in a extremely improbable situation this hoarding would be consequence of a proportional cut in expenditures on present and future goods. An action by the fractional reserve banking system that provoked an increase in the money supply in response to a hoarding resultant from non proportional expenditure cuts between present and future goods would be obstructing alterations at the agents' time preferences, clearly being a discoordinating feature for the economic system.

Besides that, free-banking doctrine, based on the "monetary (dis)equilibrium» idea, simply denies the structural uncertainty character of the world in which the agents are immerse, a factor that gives rise to the agents' desire to demand cash holdings, even after having received their income. Even if the system is not attaining some technologically optimal capable of being obtained, this does not mean that the agents must be coerced to act in a way to attain it. In addition, the agents seek to maintain «hoarded» 
a certain purchasing power, not some mere nominal balances. By raising the supply of money and press the prices upwards (ceteris paribus), the agents, if they desire the preservation of the purchasing power of their cash holdings, will hoard an additional nominal amount, or reducing their consumption and/or their investments, in a way according to their time preferences, just responding to the «ineffective» former cash holding demand.

Finally, we can conclude that the fractional reserve banking system is a practice scornful of property rights when legally institutionalized, and always economically hazardous. In an unhampered economy, it is expected to disappear.

\section{BIBLIOGRAPHY}

ANGELI, E. (2007): Hayek e a Teoria das Instituições. Campinas: IE/ UNICAMP.

BArbiÉRI, F. (2001): O Processo de Mercado na Escola Austríaca Moderna. São Paulo: FEA/USP.

- (2004): História do Debate do Cálculo Econômico Socialista. São Paulo: FEA/USP.

- (2006): «O Profits, Interest and Investiment de Hayek: Explicando a Importância da Heterogeneidade do Capital». Revista de Economia Mackenzie, vol. 4, n.․․ 4 .

BARNETT, R. (1998): The Structure Of Liberty and the Rule of Law. Oxford: Clarendon.

Biderman, C. et al. (1996): Conversas com Economistas Brasileiros. São Paulo: Editora 34.

BoettKe, P. (ed.) (1994): The Elgar Companion to Austrian Economics. Cheltenham: Edward Elgar.

- (2000) (ed.): Socialism And The Market: The Socialist Calculation Debate Revisited (vol. 9). London: Routledge.

BöHM-BAWERK, E. v. (1986) [1888]: Teoria Positiva do Capital, vol. 1. São Paulo: Nova Cultural.

CAldwell, B. (1995): The Collected Works of F.A. Hayek, vol. 9: Contra Keynes and Cambridge. Chicago: University of Chicago Press.

CARSON, K. (2006): Studies in Mutualist Political Economy. BookSurge. 
Dolan, E.G. (ed.) (1976): The Foundations of Modern Austrian Economics. Kansas City: Sheed and Ward.

EbeLING, R. (ed.) (1996): The Austrian Theory of the Trade Cycle. Auburn, AL: The Ludwig von Mises Institute.

Feijó, R. (2000): Economia e Filosofia na Escola Austríaca: Menger, Mises e Hayek. São Paulo: Nobel.

FISHER I. (1934): «The Debt-Deflation Theory of Great Depressions». Econometrica 2: 337-57.

GARrison, R. (1996): «A Subjectivist Theory of a Capital-using Economy», en G.P. O'Driscoll \& M.J. Rizzo, The Economics of Time and Ignorance, $2^{\text {nd }}$ edn. New York: Routledge.

Grinder, W. (ed.) (1977): Capital, Expectations and the Market Process.

Kansas City: Sheed Andrews and McMeel.

HAYEK, F.A. (1931a): Reflections on the Pure Theory of Money of Mr. J.M. Keynes, reimpresso em Hayek (2008).

- (1931b): The Paradox of Saving, reimpreso en Hayek (2008).

- (1936): The Mythology of Capital, reimpreso en Hayek (2008).

- (1937): Economics and Knowledge, reimpreso en Hayek (1948).

- (1941): The Pure Theory of Capital. Chicago: University of Chicago Press.

- (1942a): The Facts of the Social Sciences, reimpreso en Hayek (1948).

- (1942b): The Ricardo Effect, reimpreso en Hayek (1948).

- (1945): The Use of Knowledge in Society, reimpreso en Hayek (1948).

- (1946): The Meaning of Competition, reimpreso en Hayek (1948).

- (1948): Individualism and Economic Order. Chicago: University of Chicago Press.

- (1967a) [1931]: Prices And Production. New York: Augustus M. Kelly Publishers.

- (1967b): Studies In Philosophy, Politics and Economics. London: Routledge \& KEgan, P. (1975) [1939]: Profits, Interest, and Investment. Clifton, NJ: Augustus M. Kelley.

- (1978): Nobel Prize Winning Economist. Disponible en: <http:// www.archive.org/stream/nobelprizewinnin00haye\#page/ n7/mode/2up>. Acceso en 17/09/2009.

- (1998) [1973]: Law, Legislation and Liberty (vol. 1): Rules And Order. London: Routledge. 
- (1998) [1976]: Law, Legislation and Liberty (vol. 2): The Mirage of Social Justice. London: Routledge.

- (1998): Law, Legislation and Liberty (3 vols.). London: Routledge.

- (2002) [1968]: «Competition as a Discovery Procedure», en The Quarterly Journal Of Austrian Economics, vol. 5, n.․․ 3.

- (2008): Prices and Production and Other Works. Auburn, AL: The Ludwig von Mises Institute.

Hoppe, H. (1995): Economic Science and the Austrian Method. Auburn, AL: The Ludwig von Mises Institute.

Horwitz, S. (1996): «Capital Theory, Inflation and Deflation: The Austrians and Monetary Disequilibrium Theory Compared». Journal of the History of Economic Thought, n. ${ }^{\circ} 18$.

- (2000): Microfoundations and Macroeconomics: an Austrian Perspective. New York: Routledge.

- (2004): «Monetary Calculation and the Unintended Extended Order: The Misesian Microfoundations of the Hayekian Great Society», Review of Austrian Economics, vol. 17, n.. 4 . Huerta De Soto, J. (2005): Escola Austríaca: Mercado e Criatividade Empresarial. Lisboa: O Espírito das Leis Editora.

- (2001) [1992]: Socialismo, Cálculo Económico y Función Empresarial. Madrid: Unión Editorial.

- (2006): Money, Bank Credit, and Economic Cycles. Auburn. AL: The Ludwig von Mises Institute $\left[2^{\text {nd }}\right.$ revised edition 2009].

HüllsmanN, J. (2008): The Ethics of Money Production. Auburn, AL: The Ludwig von Mises Institute.

Keynes, J.M. (1996): Teoria Geral do Emprego, Juro e da Moeda. São Paulo: Editora Nova Cultural.

Koppl, R. (ed.) (2003): Austrian Economics and Entreprenurial Studies. Oxford: Elsevier Science.

KIRZNER, I. (1985a) [1973]: Competição e Atividade Empresarial. Rio de Janeiro: Instituto Liberal.

- (1985b): Discovery and the Capitalist Process. Chicago: University of Chicago Press.

- (1992): The Meaning of Market Process. New York: Routledge.

- (1996) [1966]: Essays on Capital and Interest: an Austrian Perspective. Cheltenham: Edward Elgar.

- (2000): The Driving Force of the Market. London: Routledge. 
KuZnetsov, Y. (1997): «Fiat Money as an Administrative Good». Review of Austrian Economics, vol. 10, n. 2 .

Lachmann, L. (1937): Uncertainty And Liquidity Preference, reimpreso en Lavoie (1994a).

- (1947): Complementarity And Substitution In The Theory of Capital, reimpreso en Grinder (1977).

- (1950): Economics As a Social Science, reimpreso en Grinder (1977).

- (1951): The Science of Human Action, reimpreso en Grinder (1977).

- (1978) [1956]: Capital and Its Structure. Kansas City: Sheed Andrews and McMeel.

- (1986a): Austrian Economics Under Fire: The Hayek-Sraffa Duel In Retrospect, reimpresso em Lavoie (1994a).

- (1986b): The Market As An Economic Process. New York: Basil Blackwell.

LANGLOIS, R. (1994): «Risk and Uncertainty», em Boettke (1994). Lavoie, D. (1985): Rivalry and Central Planning: The Socialist Calculation Debate Reconsidered, Cambridge: Cambridge University Press.

- (1994a) (ed.): Expectations and the Meaning of Institutions: Essays in Economics by Ludwig Lachmann. London, Routledge.

- (1994b): «The Interpretative Turn», en Boettke (1994).

Lewin, P. y Phelan, S. (2000): «An Austrian Theory of the Firm». Review of Austrian Economics, vol. 13: 59-79.

LonG, R. (2004): «Anti-Psychologism in Economics: Wittgenstein and Mises». Review of Austrian Economics, vol. 17, n.. 4 .

- (2009): Wittgenstein, Austrian Economics, and the Logic of Action: Praxeological Investigations. London: Routledge. Versión consultada disponible en <http://mises.org/ journals/scholar/long.pdf $>$. Acceso en 18/09/2009.

Maclachlan, F. (1993): Keynes' General Theory of Interest: A Reconsideration. New York: Routledge.

Menger, C. (1871): Grundsätze der Volkswirtschaftslehre. (Trad. port.: Princípios de Economia Política, São Paulo, Nova Cultural, 1988).

Mises, L. von. (1938): «The Non-Neutrality of Money», reimpreso en Mises (2000). 
- (1962): Ultimate Foundation of Economic Science. New York: Van Nostrand.

- (1971) [1912]: The Theory of Money and Credit. New York: The Foundation For Economic Education.

- (1990) [1920]: Economic Calculation in the Socialist Commonwealth. Auburn, AL: The Ludwig von Mises Institute.

- (1996) [1949]: Human Action: A Treatise on Economics. San Francisco: Fox\&Wilkes.

- (2000): Money, Method and the Market Process. Massachusetts: Kluwer Academic Publishers.

- (2007) [1957]: Theory and History. Auburn, AL: The Ludwig von Mises Institute.

O'Driscoll, G. (1977): Economics as a Coordination Problem: The Contributions of Freidrich A. Hayek. Kansas: Sheed Andrews and McMeel.

O'Driscoll, G. y Rizzo, M. (1996) [1985]: The Economics of Time and Ignorance, $2^{\text {nd }}$ ed. New York: Routledge.

PrYCHITKO, D. (ed.) (1998): Why Economists Disagree: An Introduction to the Alternative Schools of Thought. New York: State University Of New York.

RIzzo, M. (1990): «Hayek's Four Tendencies to Equilibrium». Cultural Dynamics.

- (2000): «Real Time and Relative Indeterminacy in Economic Theory»; en Baert, P. (ed.), Time in Contemporary Intellectual Thought. Elsevier.

Rothbard, M. (1976): «Praxeology: The Methodology of Austrian Economics», en Dolan (1976).

- (1989): «The Hermeneutical Invasion of Philosophy and Economics». Review of Austrian Economics, vol. 3.

- (2000) [1963]: America's Great Depression. Auburn. AL: The Ludwig von Mises Institute.

- (2002) [1973]: For a New Liberty. New York: Collier.

- (2004) [1962]: Man, Economy, and State. Auburn. AL: The Ludwig von Mises Institute.

Salerno, J. (1993): «Mises and Hayek Dehomogenized». Review Of Austrian Economics, vol. 6, n.․ 2.

Selgin, G. (1990) [1987]: Praxeology and Understanding. Auburn: Ludwig von Mises Institute. 
SHAPIRO, D. (1989): Reviving The Socialist Calculation Debate: A Defense of Hayek Against Lange, en Boettke (2000).

SnOWdON, B. y VANE, H. (2005): Modern Macroeconomics: It's Origins, Development and Current State. Cheltenham: Edward Elgar. Vaughn, K. (1994): Austrian Economics in America: The Migration of a Tradition. New York: Cambridge University Press.

Wicksell, K. (1962) [1898]: Interest and Prices. New York: Sentry Press. 